\title{
Response of Soft Chess (Bromus mollis) and Slender Oat (Avena barbata) to Simulated Drought Cycles
}

\author{
ANNE L. EWING AND JOHN W. MENKE
}

\begin{abstract}
Herbage production in the California annual grassland has been correlated with seasonal weather, particularly fall and spring rainfall patterns. To further examine the relationship between herbage production and rainfall pattern, 3 soil water regimes $(-1,-7,-15$ bars) simulating expected rainfall and drought events in annual rangelands were applied in seminatural annual grassland communities. Soft chess (Bromus mollis) tillers grew longest under the -7 bar water regime treatments while total plant growth was greatest under the -1 bar treatment. Tiller length and total growth of slender oat (A vena barbata) were greatest under the -1 bar treatment. Vegetative growth of slender oat was less sensitive to seasonlong soil water regimes than soft chess. The two species required different soil water conditions for maximum spring growth; soft chess put on spring growth most rapidly in the -7 bar treatment while slender oat grew fastest in the -1 bar treatment. Periodic water stress during the growing season did not reduce spring herbage production. Maximum growth and herbage production occurred only when soil water was available after March 15. Withholding water after March 15 reduced herbage production by $46 \%$.
\end{abstract}

Annual range species dominate open grassland and woodland understory on about 10 million hectares in California. Forage production and botanical composition of the forage vary annually because the herbaceous vegetation begins each growing season as seedlings.

Researchers have long attributed variation in range productivity to seasonal weather conditions. Talbot and Biswell (1942) concluded that climatic factors were the main cause for yearly fluctuations in forage yield at the San Joaquin Experimental Range in the southern Sierra foothills. Murphy (1970) found a significant correlation between yield and early growing-season rainfall at the Hopland Field Station in northern coastal California, but Duncan and Woodmansee (1975) failed to find any seasonal correlations at the San Joaquin Experimental Range. Pitt and Heady (1978) concluded that warm fall and spring temperatures coupled with adequate fall and spring precipitation at Hopland resulted in the greatest yield, but it is yet to be determined whether such empirical models can explain annual differences in productivity on drier inland annual rangelands such as the San Joaquin Experimental Range.

Pcak standing crop increases with increasing avcrage annual rainfall along a south-north rainfall gradient of 125 to $2,000 \mathrm{~mm}$ per year (Bartolome 1980). Annual rangeland at the Sierra Foothill Range Field Station in the central Sierra foothills produces 2,000 to $2,700 \mathrm{~kg} / \mathrm{ha} / \mathrm{yr}$ if soil water is limiting in April or May and

\footnotetext{
The authors are visiting assistant professor, Department of Agronomy, Oklahoma State University, Stillwater 74078 and associate professor, Department of Agronomy and Range Science, University of California, Davis 95616. The authors thank Dr. H.F. Heady, Dr. J.W. Bartolome, and Dr. L.J. Waldron, College of Natural Resources, University of California, Berkeley, and Dr. W.A. Williams, Department of Agronomy and Range Science, University of California, Davis, for their advice and critique of the manuscript.

This research was supported in part by NSF Grant No. DEB 7823641 and the California Agricultural Experiment Station.

Manuscript received September 22, 1981.
}

thereafter, but produces 2,800 to $4,600 \mathrm{~kg} / \mathrm{ha} / \mathrm{yr}$ if soil water is available until June or July (Evans et al. 1975).

Drought and rainfall pattern are undoubtedly controlling factors for herbage production in California annual grasslands, but mechanistic studies of the responses of annual species to soil water conditions are nearly lacking. In a greenhouse pot study, Gerakis et al. (1975) showed that subterranean clover (Trifolium subterraneum L.) is more drought tolerant than either soft chess (Bromus mollis) or redstem filaree (Erodium botrys). We examined plant growth parameters as they were affected by different soil water regimes designed to simulate winter and spring drought events in California annual grasslands.

\section{Methods}

Small annual grassland communities were established (14 September 1978) in Albany, Calif., using methods described by Ewing and Menke (1982). The experimental set-up completely excluded natural inputs of water so that soil water conditions were controlled by manual water applications.

Three water regime treatments (Stanhill 1950) were applied beginning 29 October 1978 , to randomly selected plots in 4 replications. Soil matric potential was measured 3 times a week and water was added to bring the soil to field capacity each time gypsum blocks indicated an average, $-1,-7$, or -15 bar matric potential at the $20 \mathrm{~cm}$ depth, for the 3 treatments respectively. Treatments closely simulated different soil drying conditions recorded in the field by Evans et al. (1975). After 15 March 1979, 2 of the 4 replicates for each treatment were allowed to dry, simulating an early end of the winter rainy season and an early beginning of summer drought. The remaining 2 replicates (controls) continued under the original treatments until 19 May 1979.

On 11 November 1978, 5 plants each of soft chess and slender oat (Avena barbata) were marked in each plot. Weekly tiller counts and tiller length measurements were recorded for each marked plant until 12 May 1979. Tiller length was measured from the ground to the tallest green plant part. Herbage, including legume and non-legume components, was clipped and oven dried on 14 June 1979 to estimate total standing crop for each plot.

Significant differences are indicated when sample means, by a pair-wise $t$-test, have less than a $5 \%$ probability of being equal $(p<.05)$; highly significant differences occur when $p<.01$.

\section{Results}

\section{Average Tiller Length}

Average tiller length per plant plotted over the growing season gave a typical growth curve for soft chess and slender oat (Figure 1). After rains in September, seeds germinated and the young plants began to grow. A period of little growth occurred in December and January, during which average tiller length actually decreased because young leaves died back. Growth began again in February, after which tiller length rapidly increased. 

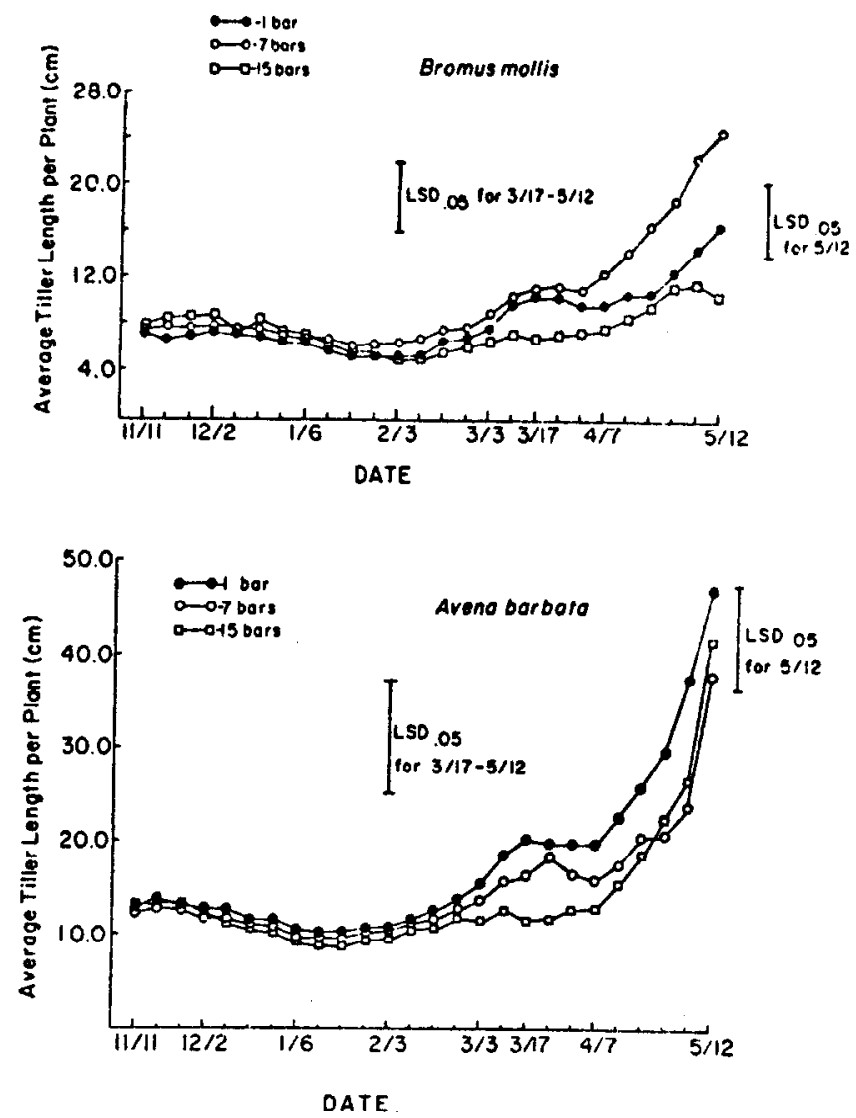

Fig. 1. Average tiller lengths of soft chess (Bromus mollis) and slender oat (Avena barbata) plants growing in 3 soil water regime treatments $(-1,-7$, -15 bars).

Initially, average tiller length of soft chess plants was similar regardless of treatment (Fig. 1). Visual separation of the curves began about 3 March, but statistically significant separation did not occur until mid-April. Final mean values (12 May) differed significantly between the -1 and -7 bar treatments. Average tiller length of plants growing in the -7 bar treatment was highly significantly different from that of plants growing in the -15 bar treatment. Maximum height growth was achieved by soft chess plants under the -7 bar water regime. Average slender oat tiller length over the growing season was nearly equal in all treatments; significant differences in length among the three treatments never occurred. Slender oat was less sensitive to soil matric potential than soft chess and showed less growth reduction under the same treatments.

Soft chess plants not receiving water after 15 March grew minimally and senesced prematurely compared to plants receiving water (Fig. 2). Dramatic differences in soft chess tiller lengths were found between watered and dried-early plants in the $e^{3}-7$ bar treatment. In the -15 bar treatment, watered soft chess plants did not achieve much more tiller growth than the unwatered plants, but they remained green and turgid. Slender oat tiller growth reductions after simulated spring drought occurred in all treatments, but the growth loss was grcatest under the -1 bar regime. Soil water availability during spring months was necessary to achieve maximum tiller growth in both species. While slender oat was fairly insensitive to short winter and spring drought periods, it was extremely sensitive to an extended spring drought.

\section{Total Tiller Length}

During fall and most of the winter, there was no difference in total tiller length of soft chess plants growing under the three soil water regime treatments (Fig. 3). Curve separation began around 3 March but statistically significant differences did not occur until April. Final mean total tiller lengths (12 May) differed significantly
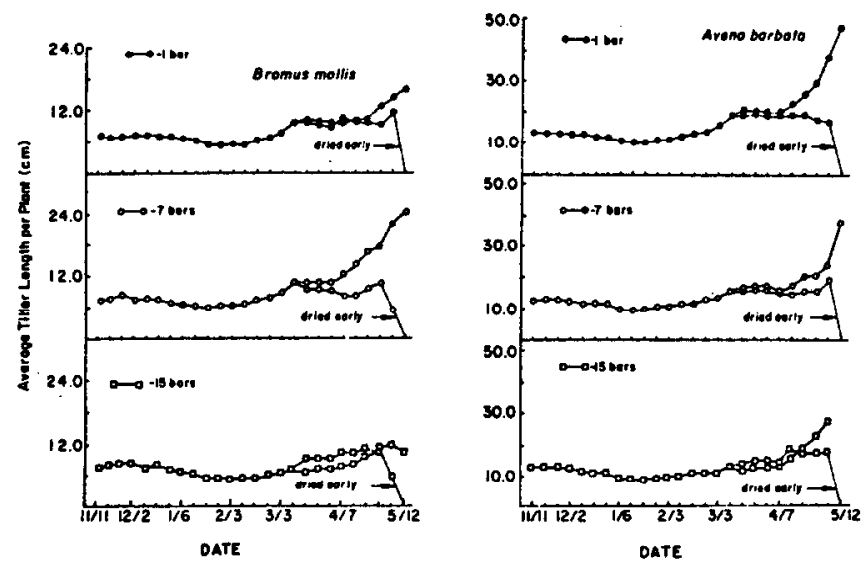

Fig. 2. A verage tiller lengths of soft chess (Bromus mollis) and slender oat (Avena barbata) plants growing in 3 soil water regime treatments $(-1,-7$, -15 bars) season-long versus simulated drought after March 15.

between the -1 and -15 bar treatments. Though total growth of soft chess plants was greatest in the -1 bar treatment, the -7 bar treatment resulted in the fastest spring growth. Linear regression showed that growth over the period 17 March through 12 May was more rapid under the -7 bar treatment. Slow but continuous growth of slender oat occurred between 11 November and 15 March, and growth was probably favored by the -1 bar treatment. After $15 \mathrm{March}$, a characteristic reduction in slender oat total tiller length followed by a resumption of growth occurred in all treatments. Final mean total tiller lengths for slender oat (12 May) differed significantly between the -1 and -15 bar treatments.

Extended spring drought caused reductions in growth, prema-
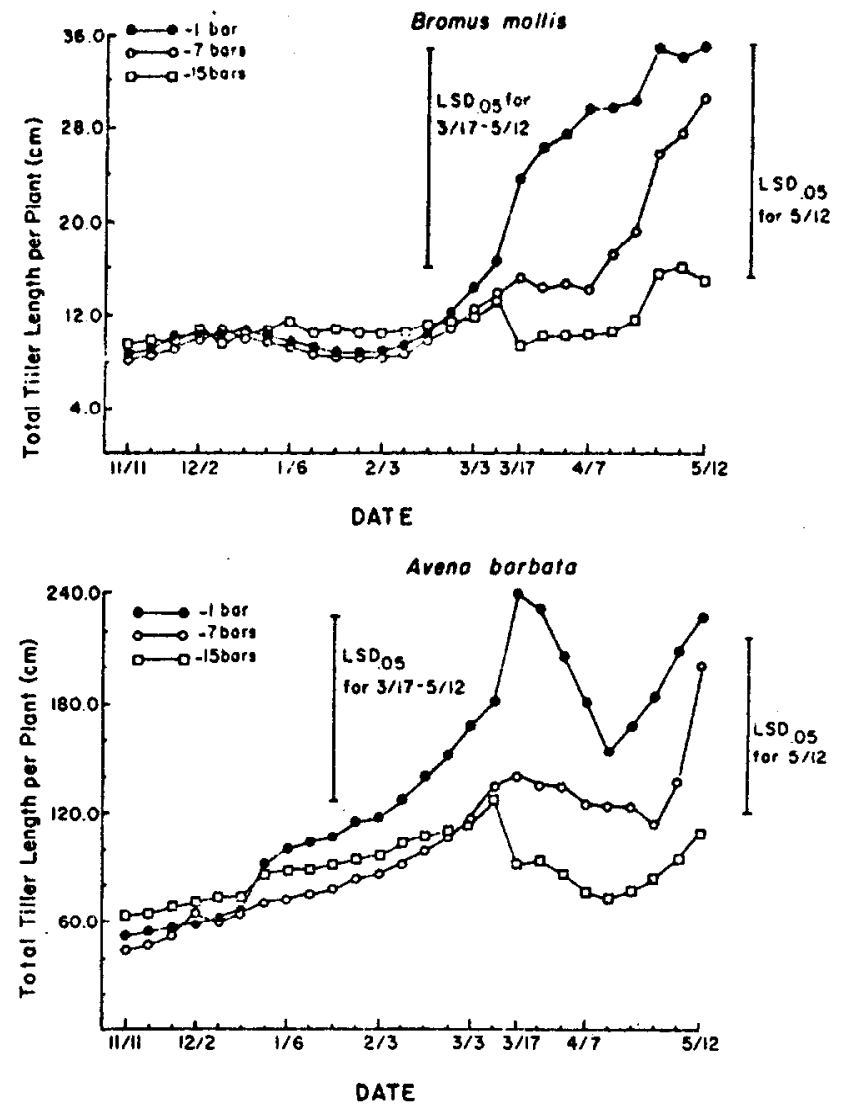

Fig. 3. Total tiller lengths of soft chess (Bromus mollis) and slender oat (Avena barbata) plants growing in 3 soil water regime treatments $(-1,-7$, -15 bars). 

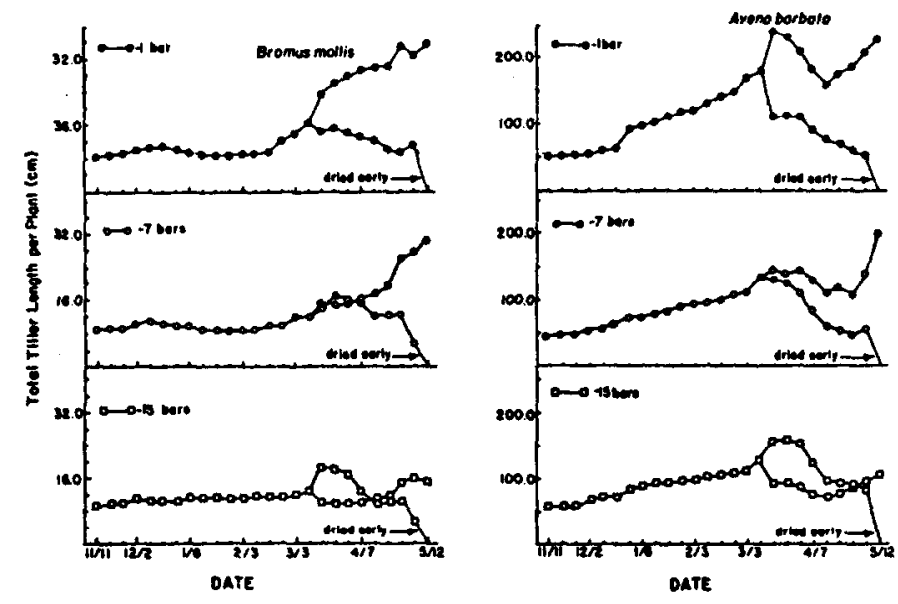

Fig. 4. Total tiller lengths of soft chess (Bromus mollis) and slender oat (Avena barbata) plants growing in 3 soil water regime treatments $(-1,-7$, -15 bars) season-long versus simulated drought after March 15.

ture senescence, and an immediate decline in total tiller length of soft chess and slender oat plants (Fig. 4).

\section{Tiller Number}

Soft chess plants developed, on the average, between 1 and 4 tillers during the growing season and exhibited a limited tendency to tiller during the winter months (Fig. 5). A significant increase in tiller number occurred under the -1 bar treatment between 3 and 31 March. Plants had between 1 and 2 reproductive tillers on 12 May, with no significant differences between treatments. Slender oat exhibited a distinct tillering pattern, and in all treatments extensive
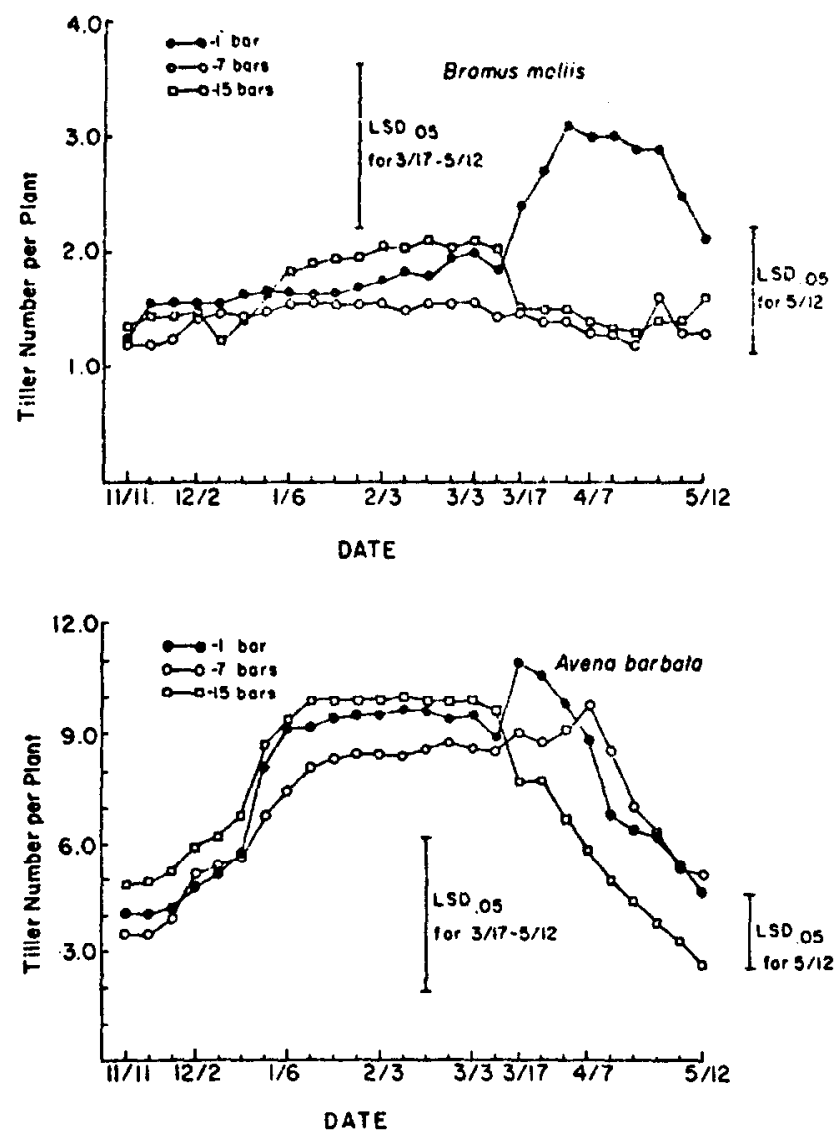

Fig. 5. Number of tillers on soft chess (Bromus mollis) and slender oat (Avena barbata) plants growing in 3 soil water regime treatments $(-1,-7$, -15 bars). tillering occurred between 11 November and 13 January. Maximum tillering was reached about 13 January, after which tiller number stabilized for 8 to 10 weeks. Just about the time rapid strong growth commended, tiller number declined as majority of the tillers senesced. This partially explains the drop in total tiller length shown in Figure 3. On 12 May, only reproductive tillers remained green, and plants had 3 to 5 reproductive tillers with no significant differences due to treatment. Slender oat plants grew similarly in separate pot trials when sunlight reached all tillers, so shading out of smaller and shorter tillers did not cause tiller senescence. Nor was tiller senescence a treatment effect since plants in all treatments showed the same response.

Soft chess and slender oat plants which experienced early cessation of the watering treatments senesced prematurely, some before the boot stage (Fig. 6). Tiller number declined rapidly after 15 March when artificial watering was stopped. The -1 bar treatment for both species showed the greatest difference after simulated early spring drought. Less difference was found for the drier treatments, especially the -7 bar and -15 bar treatments for soft ches and the -15 bar treatment for slender oat.

\section{Phenology}

Over the growing season, there were no apparent differences in development or phenology as a result of the soil water regime treatments. Individual plants flowered and matured at approximately the same time regardless of water regime. Plants which experienced early cessation of the watering treatments did not show a different course or rate of development, they merely dried before maturity.

\section{Herbage Production}

Standing crop at the end of the growing season was not significantly affected by the $-1,-7$, and -15 bar soil water regimes during the growing season (Table 1). Total production was probably greater relative to other treatments when plants experienced mild and periodic drying cycles during winter as simulated by the -7 bar treatment. Legume herbage production was greatest in the -7 bar treatment receiving water through the spring and the non-legume component was fairly constant regardless of treatment. A significant decrease in standing crop was attributable to the prolonged spring drought. On the average, a lack of a vailable soil water after 15 March reduced total herbage production by $46 \%$. Early depletion of soil water sharply reduced herbage production in both legume and non-legume herbage components, but variation was such that only the non-legume component showed a statistically significant response.

\section{Discussion}

Plant Growth and Herbage Production

Plant community response to controlled environmental factors
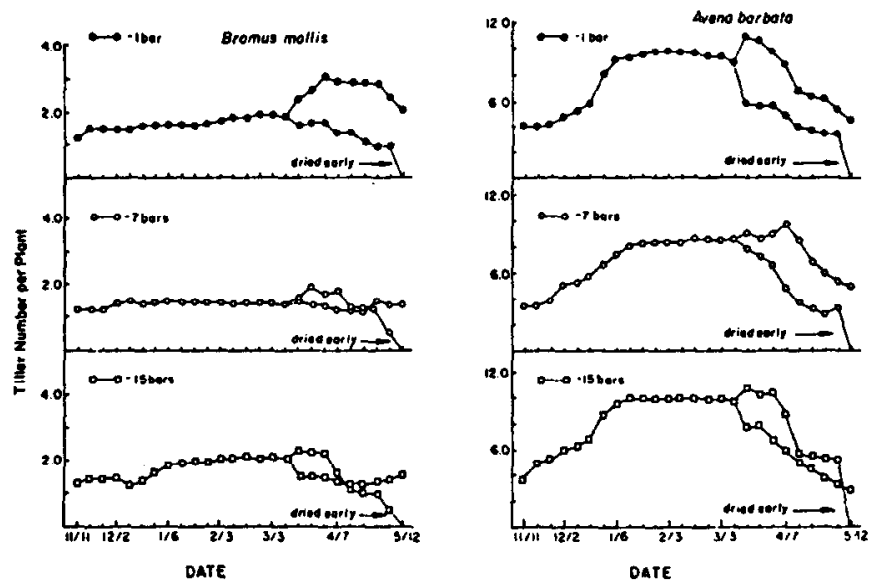

Fig. 6. Number of tillers on soft chess (Bromus mollis) and slender oat (Avena barbata) plants growing in 3 soil water regime treatments $(-1,-7$, -15 bars) season-long versus simulated drought after March 15. 
Table 1. Herbage production under 3 soil water regimes with differences in the beginning of summer drought.

\begin{tabular}{lccc}
\hline & \multicolumn{3}{c}{ Herbage production $\left(\mathrm{g} / \mathrm{m}^{2}\right)$} \\
\cline { 2 - 4 } Soil water regime & Legume & Non-legume & Total \\
\hline Controls (dried late; 19 May) & & & \\
- 1 bar & $197 \mathrm{a}^{1}$ & $844 \mathrm{a}$ & $1041 \mathrm{a}$ \\
-7 bars & $478 \mathrm{a}$ & $922 \mathrm{a}$ & $1400 \mathrm{a}$ \\
-15 bars & $256 \mathrm{a}$ & $819 \mathrm{a}$ & $1075 \mathrm{a}$ \\
Mean & $311 \mathrm{a}$ & $861 \mathrm{a}$ & $1172 \mathrm{a}$ \\
Simulated spring drought & & & \\
(dried early; 15 March) & & & \\
-1 bar & $64 \mathrm{a}$ & $514 \mathrm{a}$ & $578 \mathrm{a}$ \\
-7 bars & $100 \mathrm{a}$ & $653 \mathrm{a}$ & $753 \mathrm{a}$ \\
-15 bars & $14 \mathrm{a}$ & $547 \mathrm{a}$ & $561 \mathrm{a}$ \\
Mean & $58 \mathrm{a}$ & $572 \mathrm{~b}$ & $630 \mathrm{~b}$ \\
\hline
\end{tabular}

'Means in a column within one of 3 soil water potentials or means of control versus drought conditions followed by the same letter are not significantly different at the $5 \%$ level.

is a function of species and individual plant responses. Measurement of individual behavior is helpful, if not essential, in drawing conclusions about the community response. Soft chess and slender oat behaved differently under the same environmental conditions. Soft chess grew taller and more rapidly in spring under the moderate ( -7 bar) soil matric potential treatment compared to the wettest and dryest treatments. Slender oat grew to maximum height under the wettest ( -1 bar) soil matric potential treatment, yet grew nearly as tall with periodic drought stress.

The differences in plant growth among treatment conditions were greater for soft chess than slender oat, soft chess being more sensitive to variable soil water conditions. Soft chess grew fastest in spring under the -7 bar treatment, and an average or moderate rainfall year may favor establishment and growth of soft chess in a mixed stand. Hull and Muller (1976) reported findings in Santa Barbara County which relate to the competitive ability of soft chess under different rainfall conditions. Plant number and yield of soft chess increased in an average rainfall year while wild oat (Avena fatua) did not vary as much in plant number or yield between years.

Slender oat grew to near maximum plant height under all soil water regimes. Evans et al. (1975) found that soil water potential rarely drops below -10 bars at the Sierra Foothill Range Field Station. Slender oat growing in areas receiving similar rainfall is rarely subjected to limited soil water conditions, so restriction of slender oat to the wetter sites in California (Bartolome et al. 1980) may be related to germination requirements or other environmental conditions. Slender oat, once germinated, is a very drought tolerant species (Ewing 1981).

Mild drought during the growing season reduced individual plant growth or stimulated it, depending on the species. Because different species have different growth optima, total herbage production was not reduced by short drought periods during the growing season. Plant growth and herbage production were limited severely by a simulated end of the rainy season after 15
March; individual plants dried while still in the boot stage. Maximum herbage yield was most dependent on soil water availability after 15 March. Standing crop from plots under the dried late (19 May) treatments weighed $86 \%$ more than standing crop from plots dried after 15 March.

Evans et al. (1975) and Pitt and Heady (1978) demonstrated that the maximum herbage production requires available soil water in the spring. The claim by Murphy (1970) that forage production is predictable from November rainfall needs qualification. Our data show that maximum June production depends upon spring soil water availability. Soils which are deep and/or high in clay content are most likely to produce high yields of annual forage because water is stored and available to plants late in the spring. Shallow soils with limited water holding capacity make forage prediction based on rainfall difficult. Differences in soil types may explain partially the different results of Murphy (1970) and Duncan and Woodmansee (1975).

\section{Tillering in Slender Oat}

Slender oat tillers extensively during the growing season but only a few of those tillers set seed. The purpose of non-reproductive tillers which senesce before the rest of the plant is unknown. Perhaps it as an adaptation to grazing or mechanism to store photosynthate, minerals and water which are essential to rapid spring growth.

\section{Literature Cited}

Bartolome, J.W., M.C. Stroud, and H.F. Heady. 1980. Influence of natural mulch on forage production on differing California range sites. J. Range Manage. 33:4-8.

Duncan, D.A., and R.G. Woodmansee. 1975. Forecasting forage yield from precipitation in California's annual rangeland. J. Range Manage. 28:327-329.

Evans, R.A., B.L. Kay, and J.A. Young. 1975. Microenvironment of a dynamic annual community in relation to range improvement. Hilgardia 43:79-102.

Ewing, A.L. 1981. Drought studies in California annual grassland communities. Ph.D. Diss., Univ. California, Berkeley.

Ewing, A.L., and J.W. Menke. 1983. Reproductive potential of Bromus mollis and Avena barbata under drought conditions. Madrono. 30:159167.

Gerakis, P.A., F.P. Guerrero, and W.A. Williams. 1975. Growth, water relations and nutrition of three grassland annuals as affected by drought. J. Appl. Ecol. 12:125-135.

Hull, J.C., and C.H. Muller. 1976. Responses of California annual grassland species to variations in moisture and fertilization. J. Range Manage. 29:49-52.

Murphy, A.H. 1970. Predicted forage yield based on fall precipitation in California annual grasslands. J. Range Manage. 23:363-365.

Pitt, M.D., and H.F. Heady. 1978. Responses of annual vegetation to temperature and rainfall patterns in Northern California. Ecology 59:336350.

Stanhill, G. 1957. The effect of differences in soil moisture status on plant growth: a review and evaluation. Soil Sci. 84:205-214.

Talbot, M.W., and H.H. Biswell. 1942. The forage crop and its management, p. 13-49. In: C.B. Hutchinson and E.I. Kotok (eds.), the San Joaquin Experimental Range. California Agr. Exp. Sta. Bull. \#663.

\section{Page Charges}

Effective October 1, 1983, page charges for the Journal of Range Management will be increased to $\$ 60$ each for the first three pages and $\$ 100$ each for the fourth and each subsequent page. 